\title{
PERAN KEUNGGULAN BERSAING DALAM MEMEDIASI DAMPAK ORIENTASI PASAR DAN ORIENTASI KEWIRAUSAHAAN TERHADAP KINERJA UMKM
}

\author{
NUNGKY VIANA FERANITA* \\ HENDRA ARIS SETIAWAN \\ Program Studi Ilmu Administrasi Niaga \\ Sekolah Tinggi Ilmu Administrasi Pembangunan Jember \\ *Email: nungky_viana@yahoo.com
}

\begin{abstract}
ABSTRAK
Tujuan penelitian ini untuk mengetahui pengaruh orientasi pasar dan orientasi kewirausahaan terhadap kinerja UMKM secara langsung maupun tidak langsung dengan keunggulan bersaing sebagai variabel mediasi.

Penelitian ini merupakan penelitian kuantitatif dengan pendekatan explanatory (sebab akibat). Populasi dalam penelitian ini adalah UMKM sektor manufaktur di Kecamatan Tempurejo yang terdaftar di Dinas

Koperasi dan UMKM Kabupaten Jember sebesar 32 unit usaha. Pengambilan sampel dalam penelitian ini menggunakan teknik sampling jenuh atau teknik sensus. Sampel sebanyak 32 unit usaha. Metode analisis adalah analisis jalur (path analysis) dengan menggunakan software IBM SPSS 22. Secara keseluruhan, tujuh hipotesis yang diajukan dalam penelitian ini terdapat empat hipotesis diterima dan tiga hipotesis ditolak. Hasil pengujian hipotesis pengaruh langsung menunjukkan bahwa terdapat dua jalur yang berpengaruh signifikan, yaitu orientasi pasar terhadap keunggulan bersaing dan keunggulan bersaing terhadap kinerja usaha. Hasil pengujian hipotesis pengaruh tidak langsung menunjukkan bahwa terdapat dua jalur yang berpengaruh signifikan, yaitu orientasi pasar terhadap kinerja usaha melalui keunggulan bersaing dan orientasi kewirausahaan terhadap kinerja usaha melalui keunggulan bersaing.

Kata Kunci: Orientasi Pasar, Orientasi Kewirausahaan, Keunggulan Bersaing, Kinerja UMKM.
\end{abstract}




\section{PENDAHULUAN}

Usaha Mikro, Kecil dan Menengah (UMKM) merupakan salah satu kekuatan pendorong terdepan dalam pembangunan ekonomi di Indonesia. Gerak sektor UMKM amat vital untuk menciptakan pertumbuhan dan lapangan pekerjaan. UMKM mampu menciptakan lapangan pekerjaan lebih cepat dibandingkan sektor usaha besar. UMKM juga cukup terdiversifikasi serta memberikan kontribusi penting dalam ekspor dan perdagangan sehingga menjadi salah satu penyokong devisa negara walaupun kontribusi UMKM jauh lebih kecil jika dibandingkan dengan kontribusi usaha besar.

Perkembangan dan kontribusi UMKM dalam perekonomian Indonesia tidak dapat diragukan lagi. Jumlah UMKM dan sumbangan Produk Domestik Bruto (PDB) UMKM di Indonesia dari tahun ke tahun selalu mengalami peningkatan. Eksistensi dan peran UMKM pada tahun 2013 mencapai 57,8 juta unit usaha. Kontribusi UMKM dalam pembentukan PDB Nasional selalu meningkat sampai dengan tahun
2013 sebesar Rp 1.536.918,8 Miliar (Kementerian Koperasi dan UKM Republik Indonesia).

Masyarakat Ekonomi ASEAN (MEA) diberlakukan pada akhir 2015 membawa bebarapa tantangan bagi UMKM di Indonesia, antara lain: 1) pola pikir dari masyarakat Indonesia yang masih cenderung untuk membeli produk dari luar negeri dibandingkan dari dalam negeri; 2) keterbatasan akses finansial karena pihak perbankan ragu untuk memberikan kredit kepada UMKM; 3) keterbatasan akses pasar karena kurangnya pemanfaatan teknologi oleh UMKM; 4) kegiatan penelitian dan pengembangan produk yang masih rendah; dan 5) pelaku UMKM masih banyak yang belum memiliki perencanaan bisnis yang matang. Tantangan tersebut menuntut UMKM untuk lebih meningkatkan kinerjanya.

Penelitian ini berfokus pada pengaruh orientasi pasar dan orientasi kewirausahaan terhadap kinerja UMKM baik secara langsung maupun tidak langsung dengan 
keunggulan bersaing sebagai variabel mediasi. Banyak penelitian yang ada bertujuan untuk menganalisis pengaruh variabel-variabel ini terhadap kinerja UMKM secara langsung. Beberapa bukti empiris menunjukkan bahwa kinerja UMKM ditentukan oleh beberapa faktor yaitu orientasi pasar (Merakati et al., 2017) dan orientasi kewirausahaan (Witjaksono, 2014; Febriatmoko dan Raharjo, 2015; Sumiati, 2015; Merakati et al., 2017).

Namun, beberapa penelitian diarahkan untuk menganalisis pengaruh variabel-variabel ini terhadap kinerja UMKM melalui keunggulan bersaing karena bukti empiris menunjukkan bahwa keunggulan bersaing mampu memengaruhi kinerja UMKM (Witjaksono, 2014; Febriatmoko dan Raharjo, 2015). Keunggulan bersaing dipengaruhi oleh beberapa faktor diantaranya yaitu orientasi pasar (Febriatmoko dan Raharjo, 2015; Syukron dan Ngatno, 2016) dan orientasi kewirausahaan (Witjaksono, 2014; Syukron dan Ngatno, 2016). Penelitian sebelumnya telah menemukan bahwa ada beberapa faktor yang mempengaruhi kinerja UMKM melalui keunggulan bersaing, seperti orientasi pasar (Febriatmoko dan Raharjo, 2015; Merakati et al., 2017) dan orientasi kewirausahaan (Merakati et al., 2017).

Dibandingkan dengan 38 Kabupaten/Kota di Jawa Timur, Kabupaten Jember merupakan daerah yang cukup potensial karena memiliki jumlah UMKM tertinggi, yaitu sebesar 424 ribu yang terdiri atas sektor pertanian sebesar 243 ribu dan sisanya 181 ribu dari sektor non pertanian (Dinas Koperasi dan UKM Provinsi Jawa Timur). Tempurejo merupakan salah satu kecamatan di Kabupaten Jember dengan jumlah UMKM sebanyak 71 unit usaha, yang terdiri dari tujuh sektor yaitu sektor perdagangan, makanan, muebel, kerajinan, konveksi, pertanian dan peternakan. Jumlah UMKM di Kecamatan Tempurejo pada tahun 2016 menempati posisi ke-13 terendah di Kabupaten Jember (Dinas Koperasi dan UMKM Kabupaten Jember).

Berdasarkan hasil observasi dan wawancara yang dilakukan dengan 
beberapa pelaku UMKM, didapatkan beberapa permasalahan yang dihadapi oleh para pelaku usaha, diantaranya pendapatan mereka cenderung mengalami pasang surut yang disebabkan oleh banyaknya pesaing yang masuk dan masuknya pengusaha besar yang bermodal besar, meskipun sudah diadakan varian produk.

\section{TINJAUAN PUSTAKA}

\subsection{Manajemen Strategi}

David (2009) mengemukakan bahwa manajemen strategi adalah seni dan ilmu untuk 'formulasiimplementasi dan evaluasi' keputusan-keputusan yang bersifat lintas fungsional, yang digunakan sebagai panduan tindakan bagi fungsi Sumber Daya Manusia (SDM), pemasaran keuangan, produksi, dan lain-lain agar organisasi dapat mencapai tujuannya. Keputusan-keputusan yang bersifat lintas fungsional inilah yang dapat ditafsirkan sebagai strategi. Manajemen strategi adalah kumpulan keputusan dan tindakan yang menghasilkan perumusan dan penerapan strategi yang didesain
Berdasarkan

uraian permasalahan dan juga hasil penelitian terdahulu, maka peneliti tertarik untuk meneliti peran keunggulan bersaing dalam memediasi dampak dari orientasi pasar dan orientasi kewirausahaan terhadap kinerja UMKM sektor manufaktur di Kecamatan Tempurejo Jember.

untuk mencapai sasaran organisasi (Pearce dan Robinson, 2013).

Manajemen strategi sektor bisnis telah berkembang melalui tiga paradigma utama yaitu MarketBased View (MBV), Resource-Based View (RBV) dan Dynamic Capabilities Theory. Teori MBV lebih berorientasi ke luar perusahaan yang berlandaskan konsep Competitive Force Model yang dikembangkan oleh Porter (1980). Teori RBV lebih berorientasi ke dalam perusahaan yang berasumsi bahwa perusahaan bersaing berdasarkan sumber daya dan kemampuan (Barney, 1991). Menurut Teece (2009), kemampuan dinamis adalah kemampuan 
perusahaan untuk mengintegrasikan, membangun, dan mengkonfigurasi ulang kompetensi internal dan eksternal untuk mengatasi perubahan lingkungan yang cepat.

\subsection{Orientasi Pasar}

Ruekert (1992) memandang orientasi pasar sebagai proses budaya, perilaku, dan kegiatan yang terkait dengan menciptakan dan memuaskan pelanggan dengan terus menilai kebutuhan mereka serta ingin meningkatkan kinerja bisnis. Menurut Keskin (2006), orientasi pasar harus dikonseptualisasikan sebagai:

1. Pengumpulan informasi yang sistematis tentang pelanggan dan pesaing (baik saat ini dan potensial).

2. Analisis sistematis informasi untuk tujuan mengembangkan pengetahuan pasar.

3. Penggunaan sistematis dari pengetahuan untuk memandu strategi, pengakuan, pemahaman, penciptaan, pemilihan, implementasi

dan modifikasi.

\subsection{Orientasi Kewirausahaan}

McDougall dan Oviatt (2000) mendefinisikan orientasi kewirausahaan sebagai kombinasi perilaku inovatif, proaktif dan pengambilan risiko yang dimaksudkan untuk menciptakan nilai dalam organisasi. Suatu organisasi dapat memiliki struktur kewirausahaan, dan anggota suatu organisasi

bisa berwirausaha, dan masingmasing saling melengkapi untuk memberikan sinergi. Ciri dari suatu organisasi wirausaha menurut Ndubisi dan Agarwal (2014) yaitu:

1. Proaktif dalam memperoleh informasi tentang pelanggan dan pesaing.

2. Mengimplementasikan respons yang mencakup beberapa tingkat risiko dan ketidakpastian.

3. Memungkinkan tim memiliki tingkat otonomi yang memadai. 


\subsection{Keunggulan Bersaing}

Kottler dan Amstrong (2008) berpendapat bahwa keunggulan bersaing merupakan suatu keunggulan di atas pesaing yang dapat diperoleh dengan menawarkan nilai lebih kepada konsumen, baik melalui harga yang lebih rendah maupun dengan menyediakan manfaat yang lebih banyak untuk mendukung penetapan harga lebih mahal. Indikator yang digunakan untuk mengukur keunggulan bersaing dalam penelitian ini berdasarkan teori Porter (2008) tentang kemampuan yang harus dimiliki perusahaan untuk mencapai keunggulan bersaing dari sudut keunikan. Kemampuan tersebut meliputi:

1. Kemampuan finansial dan ekonomis.

2. Kemampuan menciptakan produk strategik.

3. Kemampuan teknologi dan proses

4. Kemampuan organisasi.

\subsection{Kinerja Usaha}

Menurut Bititci (2015), kinerja adalah efisiensi dan/atau efektivitas suatu tindakan. Efisiensi adalah jumlah sumber daya yang digunakan tindakan untuk memberikan hasil/output. Efektivitas adalah sejauh mana hasil dari suatu tindakan memenuhi harapan/persyaratan/spesifikasi kita. Terdapat beberapa model untuk pengukuran kinerja. Secara umum terdiri atas kinerja keuangan dan non-keuangan. Pengukuran kinerja perusahaan juga dapat dilakukan di lingkungan internal dan eksternal perusahaan. Indikator pengukuran kinerja usaha yang digunakan dalam penelitian ini menurut Zaenal (2012) yaitu:

1. Pertumbuhan keuntungan

2. Pertumbuhan jumlah pelanggan

3. Penjualan

4. Pertumbuhan jumlah aset.

\subsection{Usaha Mikro, Kecil dan Menengah (UMKM)}

Berbagai negara memiliki definisi yang berbeda-beda mengenai UMKM. Di Indonesia, beberapa lembaga atau instansi bahkan Undang-Undang (UU) memberikan definisi UMKM. Badan Pusat 
Statistik (BPS) memberikan definisi UMKM berdasarkan kuantitas tenaga kerja. UU No. 20 Tahun 2008 tentang Usaha Mikro, Kecil, dan Menengah mendefinisikan UMKM berdasarkan kekayaan bersih dan hasil penjualan tahunan. Sebagai acuan utama definisi UKM, kajian ini mengacu pada BPS dan UndangUndang Nomor 20 Tahun 2008 yaitu:

1. Memiliki jumlah tenaga kerja maksimal 99 orang.

2. Memiliki kekayaan bersih maksimal

Rp10.000.000.000,00

(sepuluh milyar rupiah).

3. Memiliki hasil penjualan tahunan maksimal Rp50.000.000.000,00 (lima puluh milyar rupiah).

\subsection{Hipotesis}

Hipotesis dalam penelitian ini adalah sebagai berikut:

\section{METODE PENELITIAN}

Penelitian ini merupakan penelitian kuantitatif dengan pendekatan explanatory. Unit analisis penelitian adalah organisasi

$$
\begin{aligned}
\mathrm{H}_{1} & \text { : Orientasi pasar } \\
& \text { berpengaruh terhadap } \\
& \text { keunggulan bersaing. }
\end{aligned}
$$

$\mathrm{H}_{2}$ : Orientasi kewirausahaan berpengaruh terhadap keunggulan bersaing.

$\mathrm{H}_{3}$ : Orientasi pasar berpengaruh terhadap kinerja UMKM.

$\mathrm{H}_{4}$ : Orientasi kewirausahaan berpengaruh terhadap kinerja UMKM.

$\mathrm{H}_{5}$ : Orientasi pasar berpengaruh terhadap kinerja UMKM melalui keunggulan bersaing.

$\mathrm{H}_{6}$ : Orientasi kewirausahaan berpengaruh terhadap kinerja UMKM melalui keunggulan bersaing.

$\mathrm{H}_{7}$ : Keunggulan bersaing berpengaruh terhadap kinerja UMKM.

yang diwakili pemilik/pimpinan/manajer UMKM. Lokasi penelitian yaitu UMKM di Kecamatan Tempurejo yang terdaftar 
pada Dinas Koperasi dan UMKM Kabupaten Jember.

Populasi dalam penelitian ini adalah UMKM sektor maufaktur sebanyak 32 unit usaha yang terdiri dari sektor makanan, meubel, kerajinan dan konveksi. Sampel dalam penelitian ini adalah 32 unit usaha. Metode pengambilan sampel menggunakan teknik sensus atau sampel jenuh.

Sumber data primer diperoleh dari hasil kuesioner yang isi oleh pimpinan UMKM, sedangkan data sekunder diperoleh dari Dinas Koperasi dan UMKM Kabupaten Jember.
Sedangkan variabel yang digunakan dalam penelitian ini meliputi variabel independen (X) yaitu orientasi pasar $\left(\mathrm{X}_{1}\right)$ dan orientasi kewirausahaan $\left(\mathrm{X}_{2}\right)$, variabel mediasi (Z) yaitu keunggulan bersaing, serta variabel dependen (Y) yaitu kinerja UMKM.

Analisis data yang digunakan yaitu analisis deskriptif meliputi deskripsi responden, kemudian analisis inferensial yaitu analisis jalur (path analysis). Berikut model analisis jalur yang digunakan untuk mengetahui pengaruh langsung dan tidak langsung variabel independen terhadap variabel dependen:

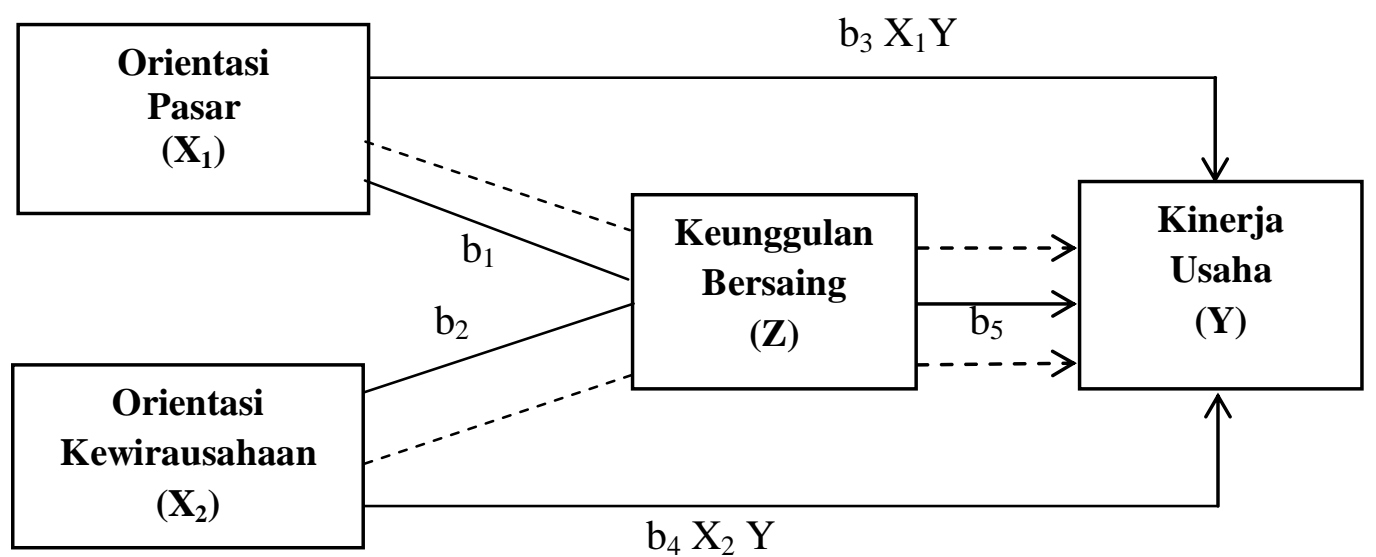

Gambar 1. Model Analisis Jalur 


\section{HASIL PENELITIAN DAN PEMBAHASAN}

\subsection{Hasil Penelitian}

Berdasarkan hasil uji validitas, seluruh item variabel memiliki nilai koefisien lebih dari 0,3494. Berdasarkan hasil uji reliabilitas, nilai koefisien cronbach Alpha seluruh variabel lebih dari 0,6. Sehingga item pernyataan seluruh varaibel valid dan reliabel.

Deskripsi umum responden berdasarkan jenis kelamin, umur, status perkawinan, pendidikan terakhir, dan lama menjalankan usaha menunjukkan responden lakilaki sebesar (65,5\%), umur responden antara 31-40 tahun sebesar (50,0\%), keseluruhan responden menikah (100\%), mayoritas responden lulusan SMP $(50,0 \%)$, dan $62,5 \%$ telah menjalankan usaha selama 4-5 tahun.

Data yang diperoleh kemudian dilakukan uji asumsi klasik yang meliputi uji normalitas, heteroskedastisitas, dan uji multikolinieritas. Berdasarkan hasil uji normalitas data penelitian berdistribusi normal (Asymp. Sign lebih dari 0,05). Berdasarkan hasil uji heteroskedastisitas, data penelitian bebas heteroskedastisitas $\left(\mathrm{t}_{\text {hitung }}<\mathrm{t}_{\text {tabel }}\right.$ dan nilai sign. $\left.>0,05\right)$. Berdasarkan hasil uji multikolinieritas, data penelitian tidak terjadi multikolinieritas (nilai tolerance lebih besar dari 0,10 dan nilai VIF lebih kecil dari 10).

Berdasarkan Tabel 1 dapat dilihat nilai koefisien jalur yang telah terstandar dari variabel independen terhadap variabel dependen sebagai berikut.

1. Orientasi Pasar $\left(\mathrm{X}_{1}\right) \quad \rightarrow$ Keunggulan Bersaing (Z).

Orientasi pasar memiliki pengaruh positif dan signifikan terhadap keunggulan bersaing $($ Beta $=0,578 ;$ sig $=0,006)$. Artinya peningkatan atau penurunan tingkat orientasi pasar, akan mampu meningkatkan atau menurunkan keunggulan bersaing.

2. Orientasi Kewirausahaan $\left(\mathrm{X}_{2}\right) \rightarrow$ Keunggulan Bersaing (Z).

Orientasi kewirausahaan memiliki pengaruh positif namun tidak signifikan terhadap keunggulan bersaing $($ Beta $=$ 
0,155; sig $=0,436)$. Artinya peningkatan atau penurunan tingkat orientasi kewirausahaan, belum mampu untuk meningkatkan atau menurunkan keunggulan bersaing.

3. Orientasi Pasar $\left(\mathrm{X}_{1}\right) \rightarrow$ Kinerja Usaha (Y).

Orientasi pasar memiliki pengaruh positif namun tidak signifikan terhadap kinerja usaha $($ Beta $=0,074 ;$ sig $=0,595)$. Artinya peningkatan atau penurunan tingkat orientasi pasar, belum mampu untuk meningkatkan atau menurunkan kinerja usaha.

4. Orientasi Kewirausahaan $\left(\mathrm{X}_{2}\right) \rightarrow$ Kinerja Usaha (Y).

Orientasi

kewirausahaan namun tidak signifikan terhadap kinerja usaha $($ Beta $=-0,049$; sig $=0,689)$. Artinya peningkatan atau penurunan tingkat orientasi kewirausahaan, belum mampu untuk meningkatkan atau menurunkan kinerja usaha.

5. Keunggulan Bersaing (Z) $\rightarrow$ Kinerja Usaha (Y).

Keunggulan Bersaing memiliki pengaruh positif dan signifikan terhadap kinerja usaha $($ Beta $=$ $0,880 ;$ sig $=0,000)$. Artinya peningkatan atau penurunan tingkat keunggulan bersaing, akan meningkatkan atau menurunkan kinerja usaha.

Tabel 1 menunjukan nilai koefisien jalur pengaruh langsung dan besarnya signifikansi. memiliki pengaruh negatif

Tabel 1. Koefisien Jalur Pengaruh Langsung

\begin{tabular}{|c|l|c|c|c|}
\hline Hipotesis & \multicolumn{1}{|c|}{ Variabel } & $\begin{array}{c}\text { Koefisien } \\
\text { Jalur }(\mathrm{p})\end{array}$ & Signifikansi & Keterangan \\
\hline $\mathrm{H}_{1}$ & $\begin{array}{l}\text { Orientasi pasar } \rightarrow \\
\text { keunggulan bersaing }\end{array}$ & 0,578 & 0,006 & Diterima \\
\hline $\mathrm{H}_{2}$ & $\begin{array}{l}\text { Orientasi kewirausahaan } \\
\rightarrow \text { keunggulan bersaing }\end{array}$ & 0,155 & 0,436 & Ditolak \\
\hline $\mathrm{H}_{3}$ & $\begin{array}{l}\text { Orientasi pasar } \rightarrow \text { kinerja } \\
\text { usaha }\end{array}$ & 0,074 & 0,595 & Ditolak \\
\hline $\mathrm{H}_{4}$ & $\begin{array}{l}\text { Orientasi kewirausahaan } \\
\rightarrow \text { kinerja usaha }\end{array}$ & $-0,049$ & 0,689 & Ditolak \\
\hline $\mathrm{H}_{7}$ & $\begin{array}{l}\text { Keunggulan bersaing } \rightarrow \\
\text { kinerja usaha }\end{array}$ & 0,880 & 0,000 & Diterima \\
\hline
\end{tabular}

Sumber: data diolah (2018) 
Berdasarkan Tabel 1 juga dapat diketahui untuk mencari pengaruh tidak langsung dan total pengaruh variabel independen terhadap variabel dependen dengan menggunakan perhitungan sebagai berikut.

1. Pengaruh variabel orientasi pasar $\left(\mathrm{X}_{1}\right)$ terhadap variabel kinerja usaha (Y)

Pengaruh langsung $\mathrm{X}_{1}$ terhadap $\mathrm{Y}$ $=0,074$

Pengaruh tidak langsung $X_{1}$ terhadap $\mathrm{Y}=0,578 \times 0,880=$ 0,509
Total pengaruh $\mathrm{X}_{1}$ terhadap $\mathrm{Y}=$ $0,074+0,509=0,583$

2. Pengaruh variabel orientasi kewirausahaan $\left(\mathrm{X}_{2}\right)$ terhadap variabel kinerja usaha $(\mathrm{Y})$

Pengaruh langsung $\mathrm{X}_{2}$ terhadap $\mathrm{Y}$ $=-0,049$

Pengaruh tidak langsung $\mathrm{X}_{2}$ terhadap $\mathrm{Y}=0,155 \times 0,880=$ 0,136

Total pengaruh $\mathrm{X}_{2}$ terhadap $\mathrm{Y}=$ $0,049+0,136=0,087$

Tabel 2. Koefisien Jalur Pengaruh Tidak Langsung

\begin{tabular}{|c|l|c|c|}
\hline Hipotesis & \multicolumn{1}{|c|}{ Variabel } & $\begin{array}{c}\text { Koefisien } \\
\text { Jalur }(\mathrm{p})\end{array}$ & Keterangan \\
\hline $\mathrm{H}_{5}$ & $\begin{array}{l}\text { Orientasi Pasar }\left(\mathrm{X}_{1}\right) \rightarrow \\
\text { Keunggulan Bersaing } \\
(\mathrm{Z}) \rightarrow \text { Kinerja Usaha (Y) }\end{array}$ & 0,509 & Diterima \\
\hline $\mathrm{H}_{6}$ & $\begin{array}{l}\text { Orientasi Kewirausahaan } \\
\left(\mathrm{X}_{2}\right) \rightarrow \text { Keunggulan } \\
\text { Bersaing }(\mathrm{Z}) \rightarrow \text { Kinerja } \\
\text { Usaha (Y) }\end{array}$ & 0,136 & Ditolak \\
\hline
\end{tabular}

Sumber: data diolah (2018)

\section{Berdasarkan Tabel 2 dapat}

diketahui nilai pengaruh tidak langsung variabel independen terhadap variabel dependen. Interpretasi dari Tabel 2 dapat dijelaskan sebagai berikut.
1. Orientasi Pasar $\quad\left(\mathrm{X}_{1}\right) \rightarrow$ Keunggulan Bersaing $(\mathrm{Z}) \rightarrow$ Kinerja Usaha (Y)

Orientasi pasar memiliki pengaruh positif signifikan terhadap kinerja usaha melalui keunggulan bersaing yaitu sebesar $(0,509)$, hal ini berarti $\mathrm{H}_{5}$ 
diterima. Artinya apabila orientasi pasar meningkat, maka hal tersebut akan meningkatkan kinerja usaha melalui keunggulan bersaing. Jika dibandingkan pengaruh orientasi pasar terhadap kinerja usaha secara langsung (lihat Tabel 1), maka dapat disimpulkan bahwa orientasi pasar tidak berpengaruh secara langsung terhadap kinerja usaha, tetapi berpengaruh secara tidak langsung (melalui variabel mediator keunggulan bersaing) terhadap kinerja usaha.

2. Orientasi Kewirausahaan $\left(\mathrm{X}_{2}\right) \rightarrow$ Keunggulan Bersaing $(\mathrm{Z}) \rightarrow$ Kinerja Usaha (Y)

Orientasi kewirausahaan memiliki pengaruh positif signifikan terhadap kinerja usaha melalui keunggulan bersaing yaitu sebesar $(0,136)$, hal ini berarti $\mathrm{H}_{6}$ diterima. Artinya apabila orientasi kewirausahaan meningkat, maka hal tersebut akan meningkatkan kinerja usaha melalui keunggulan bersaing. Jika dibandingkan pengaruh orientasi kewirausahaan terhadap kinerja usaha secara langsung (lihat Tabel 1), maka dapat disimpulkan bahwa orientasi kewirausahaan tidak berpengaruh secara langsung terhadap kinerja usaha, tetapi berpengaruh secara tidak langsung (melalui variabel mediator keunggulan bersaing) terhadap kinerja usaha.

\subsection{Pembahasan}

Hasil studi menunjukkan hipotesis $1\left(\mathrm{H}_{1}\right)$, yang menyatakan orientasi pasar berpengaruh terhadap keunggulan bersaing, diterima. Penelitian ini menemukan orientasi pasar berpengaruh positif dan signifikan terhadap keunggulan bersaing. Dengan demikian dapat dikatakan orientasi pasar (pengumpulan dan penggunaan informasi pasar, pengembangan strategi berorientasi pasar, dan implementasi strategi berorientasi pasar) merupakan salah satu faktor yang dapat mempengaruhi keunggulan bersaing. Pada perspektif empiris, hasil penelitian ini sejalan dengan hasil penelitian yang dilakukan oleh Febriatmoko dan Raharjo (2015) dan Syukron dan Ngatno (2016). 
Hasil studi menunjukkan hipotesis $2\left(\mathrm{H}_{2}\right)$, yang menyatakan orientasi kewirausahaan berpengaruh terhadap keunggulan bersaing, ditolak. Penelitian ini menemukan orientasi kewirausahaan tidak berpengaruh signifikan terhadap keunggulan bersaing. Dengan demikian dapat dikatakan orientasi kewirausahaan (proaktif, pengambilan risiko, dan otonomi) belum cukup mampu untuk meningkatkan keunggulan bersaing. Pada perspektif empiris, hasil penelitian ini sejalan dengan hasil penelitian yang dilakukan oleh Febriatmoko dan Raharjo (2015), tetapi tidak mendukung hasil penelitian Witjaksono (2014) dan Syukron dan Ngatno (2016).

Hasil studi menunjukkan hipotesis $3\left(\mathrm{H}_{3}\right)$, yang menyatakan orientasi pasar berpengaruh terhadap kinerja usaha, ditolak. Penelitian ini menemukan orientasi pasar tidak berpengaruh signifikan terhadap kinerja usaha. Dengan demikian dapat dikatakan orientasi pasar (pengumpulan dan penggunaan informasi pasar, pengembangan strategi berorientasi pasar, dan implementasi strategi berorientasi pasar) belum cukup mampu untuk meningkatkan kinerja usaha. Pada perspektif empiris, hasil penelitian ini sejalan dengan hasil penelitian yang dilakukan oleh Febriatmoko dan Raharjo (2015), tetapi tidak mendukung hasil penelitian Merakati et al. (2017).

Hasil studi menemukan hipotesis $4\left(\mathrm{H}_{4}\right)$, yang menyatakan orientasi kewirausahaan berpengaruh terhadap kinerja usaha, ditolak. Penelitian ini menemukan orientasi kewirausahaan berpengaruh tidak signifikan terhadap kinerja usaha. Dengan demikian dapat dikatakan orientasi kewirausahaan (proaktif, pengambilan risiko, dan otonomi) belum cukup mampu untuk meningkatkan kinerja usaha. Pada perspektif empiris, hasil penelitian ini tidak mendukung hasil penelitian Witjaksono (2014), Febriatmoko dan Raharjo (2015), Sumiati (2015), dan Merakati et al. (2017).

Hasil studi menunjukkan hipotesis $5\left(\mathrm{H}_{5}\right)$, yang menyatakan orientasi pasar berpengaruh terhadap kinerja usaha melalui keunggulan bersaing, diterima. Penelitian ini 
menemukan orientasi pasar berpengaruh positif signifikan terhadap kinerja usaha melalui variabel keunggulan bersaing. Dengan demikian kontribusi yang diberikan keunggulan bersaing mampu menjadi mediasi yang memberikan pengaruh antara orientasi pasar terhadap kinerja usaha. Pada perspektif empiris, hasil penelitian ini sejalan dengan hasil penelitian yang dilakukan oleh Febriatmoko dan Raharjo (2015) dan Merakati et al. (2017).

Hasil studi menunjukkan hipotesis $6\left(\mathrm{H}_{6}\right)$, yang menyatakan orientasi kewirausahaan berpengaruh terhadap kinerja usaha melalui keunggulan bersaing, diterima. Penelitian ini menemukan orientasi kewirausahaan berpengaruh signifikan terhadap kinerja usaha melalui keunggulan bersaing. Dengan demikian kontribusi yang

\section{KESIMPULAN DAN SARAN}

\subsection{Kesimpulan}

Penelitian ini menguji dan menganalisis pengaruh orientasi pasar, orientasi kewirausahaan terhadap keunggulan bersaing dan diberikan keunggulan bersaing mampu menjadi mediasi yang memberikan pengaruh antara orientasi kewirausahaan terhadap kinerja usaha. Pada perspektif empiris, hasil penelitian ini sejalan dengan hasil penelitian yang dilakukan oleh Merakati et al. (2017).

Hasil studi menunjukkan hipotesis $7\left(\mathrm{H}_{7}\right)$, yang menyatakan keunggulan bersaing berpengaruh terhadap knerja usaha, diterima. Penelitian ini menemukan keunggulan bersaing berpengaruh signifikan terhadap kinerja usaha. Dengan demikian dapat dikatakan keunggulan bersaing salah satu faktor yang memengaruhi kinerja usaha. Pada perspektif empiris, hasil penelitian ini sejalan dengan hasil penelitian yang dilakukan oleh Witjaksono (2014) dan Febriatmoko dan Raharjo (2015).

kinerja usaha baik secara langsung maupun secara tidak langsung. Sampel dalam penelitian ini sebanyak 32 UMKM sektor manufaktur (sektor makanan, 
kerajinan, konveksi,dan meubel) di Kecamatan Tempurejo Kabupaten Jember. Data yang sudah terkumpul kemudian dianalisis dengan menggunakan analisis Jalur (path analysis). Secara keseluruhan, dari tujuh hipotesis yang diajukan dalam penelitian ini terdapat empat hipotesis yang diterima dan tiga hipotesis yang ditolak. Berdasarkan pembahasan hasil penelitian, dapat ditarik beberapa kesimpulan sebagai berikut:

1. Orientasi pasar berpengaruh positif signifikan terhadap keunggulan bersaing.

2. Orientasi kewirausahaan tidak berpengaruh signifikan terhadap keunggulan bersaing.

3. Orientasi pasar tidak berpengaruh signifikan terhadap kinerja usaha.

4. Orientasi kewirausahaan tidak berpengaruh signifikan terhadap kinerja usaha.

5. Orientasi pasar berpengaruh terhadap kinerja usaha melalui keunggulan bersaing.

6. Orientasi kewirausahaan berpengaruh terhadap kinerja usaha melalui keunggulan bersaing.
7. Keunggulan bersaing berpengaruh signifikan terhadap kinerja usaha.

\subsection{Saran}

Berdasarkan keterbatasan penelitian, saran-saran yang dapat diajukan untuk penelitian yang akan datang dapat diuraikan sebagai berikut.

1. Penelitian selanjutnya mungkin bisa mengambil kelompok unit usaha yang lebih spesifik sehingga mampu menjelaskan karakteristik masing-masing unit usaha.

2. Penelitian selanjutnya diharapkan menggunakan sampel yang lebih banyak dan mencakup daerah yang lebih luas dengan keragaman (homogenitas) tinggi sehingga hasilnya dapat digeneralisasi secara nasional.

3. Penelitian selanjutnya diharapkan menambahkan variabel lain yang berpengaruh terhadap keunggulan bersaing dan kinerja usaha seperti variabel strategi bersaing dan inovasi. 


\section{DAFTAR PUSTAKA}

Barney, J. B. 1991. Firm resources and sustained competitive advantage. Journal of Management. 17(1): 99-120.

Bititci, U. S. 2015. Managing Business Performance: The Science and The Art. Chichester: John Wiley \& Sons Ltd.

David, F. R. 2009. Manajemen Strategis. Jakarta: Salemba Empat.

Febriatmoko, B. dan Raharjo, S. T. 2015. Meningkatkan Kinerja Bisnis melalui Keunggulan Bersaing Kuliner Khas Semarang (Studi pada Sentra Usaha Mikro Lumpia, Bandeng Presto dan Wingko di Kota Semarang). 2nd Conference in Business, Accounting, and Management, Universitas Islam Sultan Agung. 2(1): 139-144.

Keskin, H. 2006. Market orientation, learning orientation, and innovation capabilities in SMEs: An extended model. European Journal of Innovation Management. 9(4): 396-417.

Kotler, P. dan Amstrong, G. 2008. Prinsip-Prinsip Pemasaran. Edisi 12. Jilid 1. Jakarta: Erlangga.

McDougall, P.P. dan Oviatt, B.M. $2000 . \quad$ International entrepreneurship: the intersection of two research paths. Academy of Management Journal. 43(5): 902-908.

Merakati, I. Rusdarti, dan Wahyono. 2017. Pengaruh Orientasi Pasar, Inovasi, Orientasi Kewirausahaan melalui Keunggulan Bersaing terhadap
Kinerja Pemasaran. Journal of Economic Education. 6(2): 114-123.

Ndubisi, N. O. dan J. Agarwal. 2014. Quality performance of SMEs in a developing economy: Direct and indirect effects of service innovation and entrepreneurial orientation. Journal of Business \& Industrial Marketing. 29(6): 454-468.

Pearce, J. A. dan R. B. Robinson. 2013. Manajemen Strategis: Formulasi, Implementasi, dan Pengendalian.

Jakarta: Salemba Empat.

Porter, M. 1980. Competitive Strategy: Techniques for Analyzing Industries and Competitors. New York: The Free Press. . 2008. Strategi Bersaing (Competitive Strategi). Tangerang: Karisma Publishing Grup.

Ruekert, R.W. 1992. Developing a market orientation: an organizational strategy perspective. International Journal of Research in Marketing. Vol. 9: 224-245.

Sumiati. 2015. Pengaruh Strategi Orientasi Wirausaha dan Orientasi Pasar Pengaruhnya terhadap Kinerja Perusahaan UMKM di Kota Surabaya. Jurnal Ilmu Ekonomi dan Manajemen. 1(1): 31-44.

Syukron, M. Z. dan Ngatno. 2016. Pengaruh Orientasi Pasar dan Orientasi Kewirausahaan terhadap Inovasi Produk dan Keunggulan Bersaing UMKM Jenang di Kabupaten Kudus. 
Jurnal Administrasi Bisnis. 5(1): 24-34.

Teece, D. J. 2009. Dynamic Capabilities and Strategic Management. New York: Oxford University Press Inc.

Witjaksono, H. P. 2014. Analisis Orientasi Kewirausahaan dan Sumber Daya Internal Perusahaan terhadap Kinerja melalui Keunggulan Bersaing (Studi pada Usaha Mikro Kecil dan Menengah Furniture Kabupaten Jepara). Jurnal Bisnis STRATEGI. 23(1): 82110.

Zaenal, A. 2012. UMKM Sebagai tulang Punggung Perekonomian Nasional. Bandung: Alfabeta. 